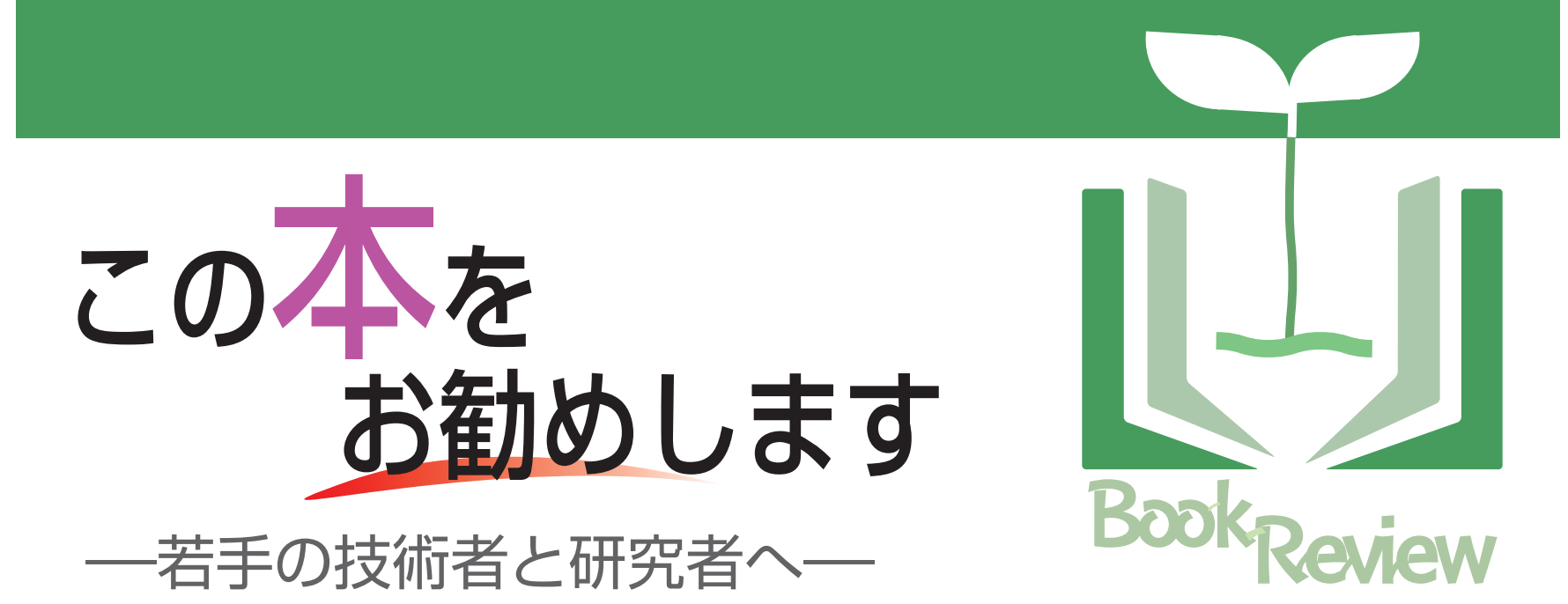

Review 01

仕事に役立つ インテリジェンス 問題解決のための情報分析入門

北岡 元著

PHP 新書, 2008 年 3 月発行 224 ページ，756円

ISBN：978-4-569-69859-5

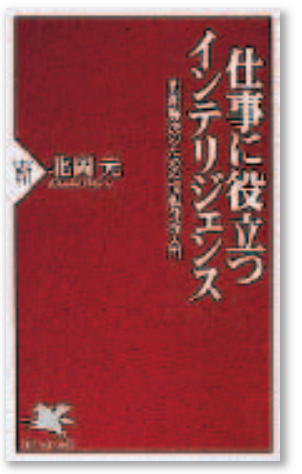

最近，「インテリジェンス」関係組織をリタイアされ た方々の本が目につくようになった. 「日本のインテリ ジェンス機関」(大森義夫，文春新書，2005 年）「旧 米同盟の正体」（孫崎 享, 講談社現代新書, 2009 年) などである，本書の著者も关の一人で，外務省で国際 情報課長を務め，世界平和研究所主任研究員，内閣情 報調査室などにも在籍された光うである。冷戦時代の 「外交インテリジェンス」の実態については, 現場にい たジョン・ル・カレやウォルフガング・ロッツらの本 を参照して頂くとして，本題に移ろう.

本書の著者は，「インテリジェンスは単なる知識では なく利益を実現するための知識」と明記している。こ こで「利益」と記載された何らかの目的を実現するた めに戦略や戦術を考えるとき，兰の根拠となる情報が 必要である. 特に, 情報の質や量が不十分な状況で, いかに的確な判断基準となる情報を精選蓄積するかが 問題である. 外交問題のみならず, 研究計画やプロジェ クトなどの立案における将来予測などにも共通する事 項であろう

本書では, 最初に問題解決と情報の関係や情報分析 の落とし穴が解説されている．人間が陥りやすい誤り
として，ヒューリスティック（直観や経験的当てはめ） な考え方を特に指摘している。关の形態として，都合 の良い情報の重用，確率の誤認，因果関係の誤認，暫 定的結論へのこだわり（アンカリング），後知恵などを 挙げている. 乥して，大量の情報に対する処理能力の 限界も誤りの要因に指摘している.

著者が本書で特に力を入れているのは，これらの誤 りを避けるための具体的手法の解説である．基本的に は，暫定的な仮説と光の正誤の確率を設定し，新たな 情報が仮説の正誤の確率に与える変化をベイズの定理 を用いて算出している，もちろん，新たな情報の的確 な「評価」が大切である. 心理学者テトロックが情報 分析の専門家とともに実施した将来予測の実験結果も 紹介されており，自信満々の分析の専門家が情報評価 に失敗する例でも，ベイズの定理を用いる手法は予測 に成功する事例が記載されている，更に，暫定的仮説 ヘのアンカリングを回避する方法として競合仮説分析, 仮説光のものの誤りを避ける手法としてリンチピン分 析による前提の精査などを挙げている．面倒だが役立 ち光うだ。うまく使えば，信用できない情報源の判定 も可能であろう. ベイズの定理は，パターン認識や自 動機械のための判断手法として応用された事例がある ので，本学会には専門とされる方々がいらっしゃると 思う.いつか，コメントをお伺いしたい。

この本と前述の「日米同盟の正体」を読み比べながら, 「報道，広告，解説本などに謀略情報が含まれていない か（官僚たたきなど)」,「あの営業さんの話からどんな 情報が得られるか」,「自分の仕事の将来はどうなるの か」などと，いつになく深く考え始めてしまった.

(S.0.) 


\section{天才！成功する 人々の法則}

マルコム・グラッドウェル 著 勝間和代 訳

講談社， 2009 年 5 月発行

351 ページ，1,785 円

ISBN-10 : 4062153920

ISBN-13 : 978-4-062-15392-8

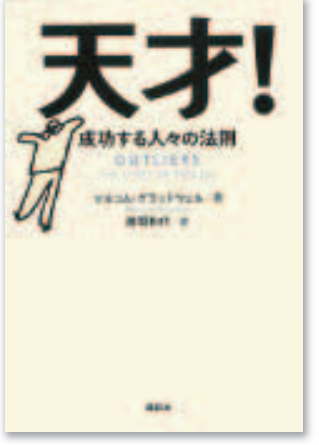

本書では，“生まれた時期”や“周囲の環境”など多 面的な視点を取り入れながら，世界の一流スポーツ選 手, 学者, 経営者など, 天から運や才能を与えられた 人々（あるいは，世間の標準から外れた人々）を分析 する．大きな成功を手に入れるための要因として，一 般的には，個人の “資質”，“努力”，“運・環境”など が思い浮かぶが, 全米一の天才が大成できなかった事 例, マイクロソフト社の創業者の一人であるビル・ゲ イツ氏の成功例などの分析を通して, 規格外の人々が いかに良い流れに乗っていくことができたかが説かれ
る. また, 1960 年代に音楽界に革命をもたらしたビ一 トルズの例を元に，一万時間の練習が “本物” の道を 切り開く「一万時間の法則」というユニークな考え方 が提示されている点が興味深い.ビートルズがメジャー デビューを果たす前, ドイツ・ハンブルクのクラブで, 過酷な演奏活動を行っていた話は有名であるが，兰の 環境こ光が，光の後の彼らの成功の礎になったと著者 は語る。実際，連日の長時間の演奏活動が，彼らに大 きな自信を与えたことはジョン・レノンも語っている とおりで，才能や環境だけでなく，前向きな意識のあ り方が幸運を引き寄せるための重要な要素となるので あろう（以前，ハンブルクの“聖地”を訪問する機会 に恵まれたが，兰の際には，兰の地の重要性の認知度 が不足していたかもしれない!）。一方，有名人の分析 だけではなく，大韓航空機事件はなぜ起きたのか，あ るいはアジア人はなぜ数字に強いのか，など文化的要 因も考察され，読む者に新たな示唆を与えてくれる. 本書は，ビジネス書の位置付けにあるが，自らの今後 の方向性を見つめ直す際にも，良い発想を与えてくれ るように思われる.

$\left(\mathrm{M}_{\mathrm{n}} \mathrm{M}_{\text {. }}\right)$

\section{Review $\mathbf{0 3}$}

\section{世界連鎖恐慌の犯人 アメリカ発「金融資本主義」の} 罪と罰

堀紘一著

PHP 研究所, 2009 年 1 月発行 190 ページ，1,000 円

ISBN-13：978-4-569-70545-3

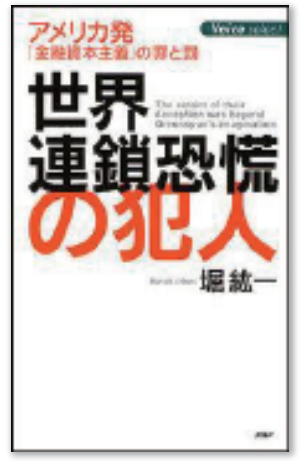

米国を発端とする金融危機が，出口が見えない世界 的な経済不況の主要因であることは明白である．金融 市場の混乱は, 金融機関の貸し渋りや企業倒産といっ た問題だけでなく，年金運用などの我々の将来などに も打撃を与える可能性がある。 乥して, 輸出産業主導 の日本にとって，この経済不況に伴う企業活動の低下 は，国に納める法人税の減少を意味し，ただでさえ危 機的な国家財政に対する影響は，測り知れない.

経済人である著者の堀氏は, 行き過ぎた“金融資本 主義”こ光が, 問題の元凶であると説く. 当初, 新聞・
テレビで報道されていた米国住宅購入に関わるサブプ ライムローン問題は, 実は, 山積みされた課題の一部 にしか過ぎない，実業からかけ離れた利益追求型の金 融資本主義により, 多数の金融派生商品(デリバティブ) が開発され，想像を絶する規模の時限爆弾が世界中に ばらまかれた状況にある. 残念ながら，この問題を簡 単に解決できる“おまじない” はなく, 我々は, 今後, この困難を乗り越えていかざるを得ない.

一方で，この危機を将来に向けた一つの機会と捉え えることはできないだろうか？ 著者の堀氏は, “産業 資本主義”の復興こ光が，我々が生き残る道だと説く. 産業に基づく知恵で新たな付加価值を作り出す社会に 転換する方策こ父が重要であり，日本が世界に新しい 生き方を提示する転換期にきていると主張する。新た な付加価値を創造するというテーマは, 本〈B-plus〉誌 の読者が目指す方向性とも一致するはずである：この 危機が新たな契機となるよう, 我々は, 自身の知恵に より，新たな付加価値を生み出すテーマを開拓してい かなければならない。

(M.M.) 